\title{
The role of Human Cytomegalovirus (HCMV) in Patients with Active Coeliac Disease (CD)
}

\author{
Inas K. Sharquie ${ }^{1^{\star}}$, Shatha F. Abdullah ${ }^{1}$, Aytan M. AL Bayati ${ }^{2}$ \\ ${ }^{1}$ Department of Microbiology \& Immunology, College of Medicine, University of Baghdad, Baghdad, Iraq \\ ${ }_{2}^{2}$ Teaching Laboratories, Medical City, Baghdad, Iraq
}

\begin{abstract}
Researchers have recently increased their focus on the link between autoimmune diseases and infections. Most of the recent research indicates that silent human cytomegalovirus (HCMV), may have diverse roles in the initiation, development, and exacerbation of autoimmune diseases, such as coeliac Disease (CD) and inflammatory bowel disease. The aim of this study is to evaluate the role of HCMV infection in Iraqi patients with CD.

Serum samples were obtained from 60 patients with CD, and from 60 healthy subjects. Enzyme-linked immunosorbent assay was used to determine the Anti-Transglutaminase IgG/IgA, Anti-gliadin IgA/ IgG, as well as the HCMV IgM/ IgG levels in the serum samples.

Significantly higher percentage of positivity for serum Anti-transglutaminase ( $100 \%$ vs $0 \%$. $\mathrm{p}=0.00$ ), serum Anti-gliadin A ( $96.7 \%$ vs. $13.3 \%, p=0.00)$ and serum Anti-gliadin $\mathrm{G}(90 \%$ vs. $13.3 \%, \mathrm{p}=0.00)$ in active CD patients from the healthy controls. Serum AntiHCMV IgM were detected equally in (3.3\%) among both in CD patients and controls whereas serum Anti-HCMV IgG in both CD patients and the controls were $(76.7 \%$ vs. $78.3 \%, \mathrm{p}=0.827)$. The mean concentrations of studied specific antibodies for CD in patient's serum are highly significant associated with positive anti-HCMV IgG compared to controls.

HCMV infections could participate in the immunopathogenesis of $\mathrm{CD}$ whether it's an autoimmune triggering factor, or may be coexist during immunosuppressive state of the disease, all of which can further worsen the disease prognosis. Further studies are needed in detail to understand HCMV immune-pathological effect and to develop new strategies for targeted therapeutic interventions.
\end{abstract}

Keywords: Human Cytomegalovirus, HCMV, CD, Coeliac Disease

\section{Introduction}

$\mathrm{CD}$ is an autoimmune disease of the proximal intestine, characterised by villous atrophy and sensitivity to the storage protein gluten, which may be symptomless $(1,2)$. The autoimmune antibody response primarily targets transglutaminase (tTG) (1). Patients with $C D$ have a gluten sensitivity that is described as an immune-mediated enteropathy (3). This contributes to inflammation of the mucosa, as well as villous atrophy and crypt hyperplasia (3). Ultimately, when tissue necessary for the functionality of the small intestine is damaged, the patient is unable to absorb certain nutrients. An extreme form of this illness, known as coeliac crisis, is life-threatening; this is due to severe diarrhoea, electrolyte imbalances, and nutritional deficiency (3).

HCMV is a beta-herpesvirus with a worldwide seroprevalence of approximately $80 \%$; this makes it the commonest human virus. It usually causes silent infection, except in immunocompromised patients or embryos, where symptoms may be severe (4).
Nikolich-Žugich and Van Lier (5) indicated that it has a genome of about $240 \mathrm{~kb}$ and possesses a potential to encode between 150 and 750 proteins (6). Research indicates that the virus spreads from person to person through close personal contact, sexual contact, blood transfusion and organ transplant (7). HCMV is thus considered a critical condition, owing to the adverse implications that it is likely to cause to patients.

Coeliac crisis, the acute form of the disease, has been noted in some case studies to be associated with HCMV infection (8), and possible links between the two diseases have been explored. A study of infants ( $<2$ years) with malabsorption found that levels of anti-HCMV antibodies were significantly higher in controls than in $\mathrm{CD}$ patients, suggesting that there is unlikely to be a causative role for HCMV in CD (9).

However, the significantly lower incidence of antiHCMV antibodies in CD patients may suggest that HCMV has a protective influence against CD in those infected (10). A study by Jansen et al. (11) found a strong inverse association between HCMV infection

\footnotetext{
${ }^{*}$ Corresponding Author: Inas K. Sharquie Department of Microbiology \& Immunology, College of Medicine, University of Baghdad, Baghdad, Iraq. Medical Collection Office, P.O. Box 61023 Postal Code 12114, Baghdad, Iraq.

E-mail: iksharquie@yahoo.com, inasksharquie@comed.uobaghdad.edu.iq Tel: 009647822241444

ORCID ID: Inas K. Sharquie: 0000-0002-4953-7365, Shatha F. Abdullah: 0000-0001-7963-5102, Aytan M. AL Bayati: 0000-0003-3247- 
and the level of anti-tTG antibody positivity, providing further evidence for this association. To establish whether HCMV is a cause of symptoms related to $\mathrm{CD}$ or coeliac crisis, it is necessary to perform serum serologic tests. These tests check for the levels of antibodies against HCMV, including IgM and $\mathrm{IgG}$. High titres of HCMV IgG indicate previous infection with HCMV, but do not necessarily indicate when the infection was active unless it's a fourfold of rising titre (12). However, if $\operatorname{IgG}$ is tested twice, with 1-3 months between the two samples, it can be determined whether the person has been infected recently; this will be the case if the first sample tests negative while the second tests positive. IgM tests for primary infection with HCMV (13). The titres of HCMV antibodies for patients with CD can help determine the role of HCMV in CD progression, when compared to those for a control group of subjects without $\mathrm{CD}$.

Patients and Methods: A total of 120 blood samples were collected, from patients with $\mathrm{CD}$ and from healthy subjects, after obtaining the approval of the ethics committee of the college of medicine, University of University of Baghdad, and with the formal consent of the patients and the healthy subjects.

The patient study group comprised 60 patients (30 females and 30 males) their ages ranged from 2-60 years old, they diagnosed with $\mathrm{CD}$ based on raised human tissue anti-transglutaminase screen for both $\operatorname{IgG} / \operatorname{IgA}$ in their sera, previous endoscopic duodenal biopsy (26 of them had significant duodenal changes since 2 years) and all of them were respond to gluten free diet; All studied patients were stable at least for the last 6 months and attended Gastroenterology and Liver diseases Teaching Hospital, Baghdad, Iraq for monitoring and follow up. The control group comprised 60 healthy subjects (26 males and 34 females), and their ages ranged from 2-52 years old. Serum blood samples were collected aseptically from both groups, and analysed for Anti-Transglutaminase screen, Anti-Gliadin IgA, and Anti-Gliadin IgG, using ELISA kits from DIALAB in Austria and following the manufacturer's instructions. Briefly, 100ul of calibrators, control and patient samples were added to the microwell plates, which were then incubated for 30 minutes at room temperature. Next, the contents of the microwells were discarded and washed three times with a wash solution. Then, the enzyme conjugate was added to each well, and the plates were incubated for 15 minutes at room temperature. Next, the contents of the microwells were discarded and washed three times with a wash solution. Then, the substrate solution was added to each well, and the plates were incubated for 15 minutes at room temperature. Then, the stop solution was added to each well, and the plates were incubated for five minutes at room temperature. Finally, at $450 \mathrm{~nm}$ the microwell plate was read by spectrophotometer, and the results were calculated.

For IgG and IgM antibodies to CMV we used CMV $\operatorname{IgM}$ and $\operatorname{IgG}$ ELISA test kits from Foresight in Germany, again following the manufacturer's instructions.

Statistical Analysis: The statistical analysis was done using the SPSS statistical package (Version 20; SPSS, IBM), with Microsoft Excel (2010) being used to create the graphics in this paper. Also employed were a chi-square $\left(\chi^{2}\right)$ test and an odds ratio test-to compare qualitative variables (demographic parameters and assays as positive or negative results)while a student's $(\mathrm{T})$ test Pearson Correlation ( $\mathrm{r}$ ) was used for a comparison between quantitative variables. As a final point, the statistical significance difference (P-value) was accepted at the level of $\mathrm{P}<0.05$.

\section{Results}

The participants in this study were 60 patients afflicted by $\mathrm{CD} ; 30$ females and 30 males, with a mean age of $23.4 \pm 18.429$ years. Additionally, 60 healthy individuals were involved as controls; 26 males and 34 females, with a mean age of $17.36 \pm$ 14.85 years. A demographic study revealed that sex and age distribution of $\mathrm{CD}$ and control groups were similar, there were statistically non-significant differences $(p=0.058)$ between the mean ages of the patients with $\mathrm{CD}$ and the apparently healthy controls. Table 1 shows that the mean levels of serum antitransglutaminase screen, anti-gliadin $\mathrm{A}$ and antigliadin $G$ were significantly higher in patients with celiac disease compared to controls $(121.46 \pm 87.97$ vs $10.45 \pm 5.49 ; 114.44 \pm 78.14$ vs $6.14 \pm 3.86$; and $83.14 \pm 84.23$ vs $7.21 \pm 4.43)$ respectively with $\mathrm{p}$ value of 0.000 . Serum concentration of anti-HCMV $\operatorname{IgG}$ revealed a significant difference in patients compared to healthy controls $(88.02 \pm 55.09$ vs 66.75 \pm 38.56) with $\mathrm{p}=0.028$.

Furthermore, this study showed that the CD patients had an increased frequency and percentage of a positive results (above the cut-off value) of the antibodies studied (anti- transglutaminase screen, antigliadin A and anti-gliadin $G$ ), compared to the negative results (below the cut-off value) in the control group with a highly statistical significant differences $(p=0.00)$. The details are provided in table 2.

However, HCMV IgM antibodies were detected equally in $2(3.3 \%)$ of both cases and controls 
Table 1. Mean concentrations of studied antibodies in the serum of studied groups

\begin{tabular}{lcccc}
\hline & \multicolumn{3}{c}{ Mean concentration $(\mathrm{U} / \mathrm{mL}) \pm \mathrm{SD}$} \\
\cline { 2 - 5 } $\begin{array}{l}\text { Study } \\
\text { groups(no.) }\end{array}$ & $\begin{array}{c}\text { Anti-trans } \\
\text { glutaminase screen }\end{array}$ & Anti-gliadin A & Anti-gliadin G & Anti-CMV-IgG \\
\hline Patients(60) & $121.46 \pm 87.97$ & $114.44 \pm 78.14$ & $83.14 \pm 84.23$ & $88.02 \pm 55.09$ \\
Controls(60) & $10.45 \pm 5.49$ & $6.14 \pm 3.86$ & $7.21 \pm 4.43$ & $66.75 \pm 38.56$ \\
p- value & $\mathrm{p}=0.00$ & $\mathrm{p}=0.00$ & $\mathrm{p}=0.00$ & $\mathrm{p}=0.028$ \\
\hline
\end{tabular}

Table 2. Percentages of specific antibody assays results according to studied groups

\begin{tabular}{lccc}
\hline$*$ Antibody $(\mathrm{U} / \mathrm{ml})$ & $\begin{array}{c}\text { Patients } \\
\text { No. }(\%)\end{array}$ & $\begin{array}{c}\text { Controls } \\
\text { No. }(\%)\end{array}$ & $\begin{array}{c}\mathrm{p} \text {-value } \\
\text { Odd ratio(OD) }\end{array}$ \\
\hline $\begin{array}{l}\text { Anti-trans Glutaminase screen: } \\
\text { Positive }\end{array}$ & $60(100)$ & $0(0)$ & $\mathrm{p}=0.00$ \\
Negative & $0(0)$ & $60(100)$ & $\mathrm{p}=0.00$ \\
Anti-gliadin A: & $58(96.7)$ & $8(13.3)$ & $\mathrm{OD}=7.25$ \\
Positive & $2(3.3)$ & $52(86.7)$ & $\mathrm{p}=0.00$ \\
Negative & & & $\mathrm{OD}=13.5$ \\
Anti-gliadin G: & $54(90)$ & $8(13.3)$ & \\
Positive & $6(10)$ & $52(86.7)$ & \\
Negative & & & \\
\hline
\end{tabular}

*Cut-off values for anti- transglutaminase screen, anti-gliadin $\mathrm{A}$ and anti-gliadin $\mathrm{G}$ were $(>31.8,>6.9$, and $>8.1)$ respectively

$(p=1.00)$. Similarly, the results for serum Anti-HCMV IgG with a positive predominant in both $\mathrm{CD}$ patients (Positive 46, 76.7\% and Negative 14, 23.3\%) and the control group (Positive 47, 78.3\% and Negative 13, $21.7 \%)$, with $(\mathrm{p}=0.827, \mathrm{p}>0.05)$. Table3.

The mean concentrations of anti-transglutaminase screen, anti-gliadin $A$ and anti-gliadin $G$ in serum samples of $\mathrm{CD}$ patients are highly significant associated with positive anti-HCMV IgG in sera which represents $(77.1 \pm 90.08,71.94 \pm 81.5$ and 54.09 \pm 76.8 ) respectively compared to controls with positive anti HCMV-IgG at a mean concentrations of anti-trans glutaminase screen, anti-gliadin $\mathrm{A}$ and antigliadin $G$ of $(16.7 \pm 10.4, \quad 15.2 \pm 8.7, \quad 9.8 \pm 6.2)$ respectively. ( two tailed $\mathrm{p}$-value $=0.0001)$.See table 4 .

\section{Discussion}

Many studies show that intestinal viruses can induce the immune system to overreact to gluten and trigger the development of celiac disease (14). The major finding of this study that there was a high statistically significant association between serum levels of specific antibodies for CD with HCMV infection. Although all of our patients are free from symptoms, silent HCMV infection is common that may reactivate and elicit coeliac crisis. A wide range of HCMV characteristics involves the virus in many autoimmune disorders, this attributed to its replication in multiple tissues during lytic phase, lifelong viral persistency with intermittent episodes of latency and acute reactivating phases, large complex genome, molecular mimicry and extensive modulation of adaptive and innate immunity incriminate HCMV in autoimmunity (15).

HCMV infections in the intestine are common especially in immunocompromised patients. It infects epithelial cells, histiocytes, fibroblast cells, and the cell of smooth muscle. throughout the lytic phase of CMV infection that may ends with tissue necrosis, erosion, and ulceration of mucosa with bleeding (14). A study by Kaufman et al. stated that gastrointestinal CMV disease can be manifested with numerous of symptoms and various endoscopical features, it is associated with esophagitis, gastritis and colitis. CMV duodenitis characterized by marked inflammatory changes and erythema of intestinal mucosa, also intestinal perforation may occur (16). In addition, CMV disease often complicates ulcerative colitis (UC) and Crohn's disease; it was recorded that the occurrence of cytomegalovirus enterocolitis in $4.6 \%$ of ulcerative colitis patients and $0.8 \%$ in Crohn's disease (17).

During CMV infections a variety of immune elements overlap. Persistent CMV in human chronic infections resulted by prolong exposure to viral antigens, can 
Table 3. Detection of HCMV-IgM/IgG in studied groups

\begin{tabular}{lcccc}
\hline \multirow{2}{*}{ Assays } & & \multicolumn{2}{c}{ Studied groups } & Pearson \\
\cline { 3 - 4 } & & $\begin{array}{c}\text { Patients } \\
\text { No. }(\%)\end{array}$ & $\begin{array}{c}\text { Controls } \\
\text { No. }(\%)\end{array}$ & $\begin{array}{c}\text { Chi-Square } \\
(\mathrm{p} \text {-value })\end{array}$ \\
\hline Anti - & Positive & $2(3.3)$ & $2(3.3)$ & $\mathrm{p}=1.00$ \\
HCMV IgM & $\begin{array}{c}\text { Negative } \\
\text { Positive }\end{array}$ & $58(96.7)$ & $58(96.7)$ & \\
Anti-HCMV & $(>16.5)$ & $46(76.7)$ & $47(78.3)$ & \\
IgG U/mL & $\begin{array}{l}\text { Negative } \\
(<16.5)\end{array}$ & $14(23.3)$ & $13(21.7)$ & $\mathrm{p}=0.827$ \\
& & & \\
\hline
\end{tabular}

Table 4. Mean concentration of specific antibodies assays in HCMV infected study groups

\begin{tabular}{lcccc}
\hline \multirow{2}{*}{ Study groups } & CMV-IgG & \multicolumn{2}{c}{ Mean concentration (U/mL) \pm SD } \\
\cline { 3 - 5 } & No. $(\%)$ & $\begin{array}{c}\text { Anti-trans } \\
\text { glutaminase screen }\end{array}$ & Anti-gliadin A & Anti-gliadin G \\
\hline Celiac patients & $\begin{array}{c}\text { Positive } \\
\text { 46(76.7) }\end{array}$ & $77.1 \pm 90.08$ & $71.94 \pm 81.5$ & $54.09 \pm 76.8$ \\
& $\begin{array}{c}\text { Negative } \\
\text { Controls }\end{array}$ & $28.7 \pm 34.8$ & $32.5 \pm 43.6$ & $17.5 \pm 16.4$ \\
& $\begin{array}{c}\text { Positive } \\
\text { (4) }\end{array}$ & $16.7 \pm 10.4$ & $15.2 \pm 8.7$ & $9.8 \pm 6.2$ \\
& $\begin{array}{c}\text { Negative } \\
13(21.7)\end{array}$ & $5.1 \pm 3.2$ & $5.3 \pm 4.9$ & $3.9 \pm 1.7$ \\
p- value & $* 1.000$ & $* * 0.0001$ & $* * 0.0001$ & $* * 0.0002$ \\
\hline
\end{tabular}

*using chi square test

**using paired t-test

lead to increased expression of Programmed death 1 (PD-1) which, in turn, activate $\mathrm{T}_{\text {regs }}$ and subsequent $\mathrm{T}$ cell exhaustion. Consequently these immune effectors plays an essential role in immune evasion, immune tolerance, autoimmune diseases, and host responses to virus infections (18).

In agreement with the mixed results of previous research, which has found that HCMV could be a causative of $\mathrm{CD}(8,9)$. It appears from the wider literature that any model for viral autoimmune induction in $\mathrm{CD}$ will be multifactorial, and may vary from population to population or age-group to agegroup. A number of other candidate viruses and microorganisms have also been implicated in the development of $\mathrm{CD}$, both causative and protective, including Helicobacter pylori (19), Rubella (20), Epstein-Barr Virus (21), Rotavirus (22) and Tuberculosis (1). Other research has focused on the aetiology of $\mathrm{CD}$ beyond viral infection, such as the gut microbiota (23).

Our results regarding serum biomarkers confirm the findings of previous studies, especially the use of Anti-transglutaminase as it is one of the best diagnostic marker $(24,25)$. However, the wider literature also shows that CD remains underdiagnosed, suggesting that other novel biomarkers should be investigated. Around $90 \%$ of those with $\mathrm{CD}$ are symptom free, like those in the present study; in these cases, serum biomarkers of the active disease, such as Anti-transglutaminase, become more effective diagnostic markers (26). Markers of gene expression have been further proposed. Nearly all CD patients are genetically HLA-DQ2 and/or HLA-DQ8 positive, so genotyping could avoid jejunal biopsy in some patients; however, this is expensive (27). The Reg I $\alpha$ gene and protein, involved in tissue regeneration, may provide a better alternative (28). In particular, Reg I $\alpha$ expression appears to be high at the onset of the disease, when tissue changes are occurring; therefore, different markers may be suggested at different stages of the disease (29).

The present study had a number of strengths, including the use of gender- and age-matched CD and healthy control groups, and the analysis of a range of serum antibodies. However, the study also had several limitations. While the study was large enough, to justify a relatively high level of confidence in finding statistically significant relationships where they exist, 
the restriction to 120 blood samples within Iraq means that the results are not necessarily generalisable to the worldwide population of $\mathrm{CD}$ patients. Another limitation is the difficulty in obtaining a biopsy for better understanding the virus- disease relationship and to diagnose the extent of tissue damage induced by CMV in relation to disease stages. Finally, poor patient compliance to gluten free diet and associated other autoimmune diseases must be assessed.

As expected, there was a strong relationship between $\mathrm{CD}$ antibodies against transglutaminase and the gliadins targeted in the autoimmune disease and HCMV infection. Infection with HCMV, a common and lifelong but otherwise silent, upon reactivation, HCMV can trigger the immune system response to gluten that could lead to coeliac disease, so that the use of safe antiviral drugs against CMV could improve prognosis. It is likely that HCMV, in common with a number of other infections, has multi-directional interactions in CD development, which require significant further research to elucidate fully.

\section{References}

1. Lerner A, Arleevskaya M, Schmiedl A, Matthias T. Microbes and Viruses Are Bugging the Gut in Celiac Disease. Are They Friends or Foes? Front Microbiol 2017; 8: 1392.

2. Anis S, Kumar R, Abbas Z, Hassan SM, Luck $\mathrm{NH}$, Muzaffar R. Coeliac disease and multiple immunodeficiencies: case report of a diagnostic dilemma. J Pak Med Assoc 2012; 62: 730-732.

3. Chen A, Linz CM, Tsay JL, Jin M, El-Dika SS. Celiac Crisis Associated with Herpes Simplex Virus Esophagitis. ACG Case Rep J 2016; 3(4): e159-e.

4. Rafailidis PI, Mourtzoukou EG, Varbobitis IC, Falagas ME. Severe cytomegalovirus infection in apparently immunocompetent patients: a systematic review. Virol J 2008; 5: 47.

5. Nikolich-Žugich J, van Lier RAW. Cytomegalovirus (CMV) research in immune senescence comes of age: overview of the 6th International Workshop on CMV and Immunosenescence. Geroscience 2017; 39: 245249.

6. Chiereghin A, Potena L, Borgese L, Gibertoni D, Squarzoni D, Turello G, et al. Monitoring of Cytomegalovirus (CMV)-Specific Cell-Mediated Immunity in Heart Transplant Recipients: Clinical Utility of the QuantiFERON-CMV Assay for Management of Posttransplant CMV Infection. J Clin Microbiol 2018; 56: e01040-17.

7. Haese N, Burg J, Ando T, Jones I, Kreklywich C, Orloff S, et al. Depletion of macrophages from Cytomegalovirus (CMV) latently infected donor allografts decreases CMV mediated immunopathology and prevents CMV-accelerated chronic rejection. The Journal of Immunology 2018; 200: 55.25-55.25.

8. Kelly E, Cullen G, Aftab AR, Courtney G. Coeliac crisis presenting with cytomegalovirus hepatitis. European journal of gastroenterology \& hepatology 2006; 18: 793-795.

9. Nemes E. Pathologic antibody responses in celiac disease: specificity and immunological correlations. PhD Thesis. University of Debrecen: Debrecen. 2008. Avaliable from: https://dea.lib.unideb.hu/dea/bitstream/handle/ 2437/31682/Nemes_Eva_tezis_angol.pd?sequen $\mathrm{ce}=7$ \&isAllowed $=\mathrm{y}$

10. Plot L, Amital H, Barzilai O, Ram M, Nicola B, Shoenfeld Y. Infections May Have a Protective Role in the Etiopathogenesis of Celiac Disease. Annals of the New York Academy of Sciences 2009; 1173: 670-674.

11. Jansen MA, van den Heuvel D, van der Zwet KV, Jaddoe VW, Hofman A, Escher JC, et al. Herpesvirus Infections and Transglutaminase Type 2 Antibody Positivity in Childhood: The Generation R Study. Journal of pediatric gastroenterology and nutrition 2016; 63: 423-430.

12. CDC. Cytomegalovirus (CMV) and congenital CMV infection, Centers for Disease Control and Prevention. 2020. Available from: https://www.cdc.gov/cmv/clinical/lab-tests.html

13. Ross SA, Novak Z, Pati S, Boppana SB. Overview of the diagnosis of cytomegalovirus infection. Infect Disord Drug Targets 2011; 11: 466-474.

14. Brown JJ, Jabri B, Dermody TS. A viral trigger for celiac disease. PLoS Pathog 2018; 14:e1007181-e.

15. Halenius A, Hengel H. Human cytomegalovirus and autoimmune disease. BioMed research international 2014; 2014: 472978.

16. Kaufman HS, Kahn AC, Iacobuzio-Donahue C, Talamini MA, Lillemoe KD, Hamilton SR. Cytomegaloviral enterocolitis: clinical associations and outcome. Diseases of the colon and rectum 1999; 42: 24-30.

17. You DM, Johnson MD. Cytomegalovirus infection and the gastrointestinal tract. Current gastroenterology reports 2012; 14: 334-342.

18. Weinberg A, Bosch R, Bennett K, Tovar-Salazar A, Benson CA, Collier AC, et al. Regulatory T cells and the risk of CMV end-organ disease in patients with AIDS. Journal of acquired immune deficiency syndromes 2014; 66: 25-32. Epub 2014/01/01.

19. Lebwohl B, Blaser MJ, Ludvigsson JF, Green PHR, Rundle A, Sonnenberg A, et al. Decreased risk of celiac disease in patients with Helicobacter pylori colonization. Am J Epidemiol 2013; 178: 1721-1730.

20. Muhsin JM. Study the possible Seropositivity connection of EBV, Rubella Virus \& CMV

East J Med Volume:26, Number:2, April-June/2021 
infection with four groups of autoimmune diseases in sample of Iraqi patients. Al-Nisour Journal for Medical Sciences 2019; 1: 108-117.

21. Perfetti V, Baldanti F, Lenti MV, Vanoli A, Biagi F, Gatti M, et al. Detection of Active EpsteinBarr Virus Infection in Duodenal Mucosa of Patients With Refractory Celiac Disease. Clinical gastroenterology and hepatology : the official clinical practice journal of the American Gastroenterological Association 2016; 14: 12161220.

22. Dolcino M, Zanoni G, Bason C, Tinazzi E, Boccola E, Valletta E, et al. A subset of antirotavirus antibodies directed against the viral protein VP7 predicts the onset of celiac disease and induces typical features of the disease in the intestinal epithelial cell line T84. Immunologic research 2013; 56: 465-76.

23. Nylund L, Kaukinen K, Lindfors K. The microbiota as a component of the celiac disease and non-celiac gluten sensitivity. Clinical Nutrition Experimental 2016; 6: 17-24.

24. Vermeersch P, Geboes K, Marien G, Hoffman I, Hiele M, Bossuyt X. Diagnostic performance of IgG anti-deamidated gliadin peptide antibody assays is comparable to $\operatorname{IgA}$ anti-tTG in celiac disease. Clinica chimica acta; international journal of clinical chemistry 2010; 411: 931-935.
25. Bragde H, Jansson U, Fredrikson M, Grodzinsky E, Soderman J. Potential blood-based markers of celiac disease. BMC gastroenterology 2014; 14: 176.

26. Vives-Pi M, Takasawa S, Pujol-Autonell I, Planas R, Cabre E, Ojanguren I, et al. Biomarkers for diagnosis and monitoring of celiac disease. Journal of clinical gastroenterology 2013; 47: 308-313.

27. Clouzeau-Girard H, Rebouissoux L, Taupin JL, Le Bail B, Kalach N, Michaud L, et al. HLA-DQ genotyping combined with serological markers for the diagnosis of celiac disease: is intestinal biopsy still mandatory? Journal of pediatric gastroenterology and nutrition 2011; 52: 729-33.

28. Planas R, Pujol-Autonell I, Ruiz E, Montraveta M, Cabre E, Lucas-Martin A, et al. Regenerating gene Ialpha is a biomarker for diagnosis and monitoring of celiac disease: a preliminary study. Translational research : the journal of laboratory and clinical medicine 2011; 158: 140-145.

29. Tsuchida C, Sakuramoto-Tsuchida S, Taked M, Itaya-Hironaka A, Yamauchi A, Misu M, et al. Expression of REG family genes in human inflammatory bowel diseases and its regulation. Biochemistry and biophysics reports 2017; 12: 198-205. 